\title{
APPLYING IBN 'ARABĪ'S CONCEPT OF TAJALLİ: A Sufi Approach to Environmental Ethics
}

\author{
Bambang Irawan \\ Syarif Hidayatullah State Islamic University Jakarta, Indonesia \\ Corresponding Author: bambang.irawan@uinjkt.ac.id \\ Ismail Fahmi Arrauf Nasution \\ Institut Agama Islam Negeri Langsa, Indonesia \\ ismailfahmiarraufnasution@iainlangsa.ac.id \\ Hywel Coleman \\ University of Leeds, United Kingdom \\ h.coleman@leeds.ac.uk
}

Article history: Received: 19 November 2020; Accepted: 10 February 2021; Published: 22 April 2021

\begin{abstract}
:
This article examines the Sufi concept of tajali and its application to environmental ethics. This study uses descriptive and productive interpretation to analyze the data which are extracted from the main works of Ibn 'Arabī, namely Fușūs al-Hikam and alFutūhāt al-Makkiyya. It finds that Ibn 'Arabì's concept of tajali can be understood not only in its philosophical sense but also in its spiritual and moral sense to develop a new approach to environmental ethics. This research has valid implications for taking a new direction in the study of mystic Islam and environmental ethic by incorporating tajalli and other Sufi doctrines such as wah dat al-wujūd, mah abbah, and ma' rifah.
\end{abstract}

Keywords: Ibn 'Arabi'; Sufism; Tajalit; Environmental Ethics; Environmental Conservation.

\section{A. Introduction}

$\mathrm{G}$ lobal warming and the present ecological crisis have invited many religious scholars to identify the moral factors responsible for wasting and depleting the limited natural resources available to us. ${ }^{1}$ As Muslim scholars, we face the challenge of examining our traditions and finding inspiration and guidance - anything that could help us in our collective attempt to forestall this global disaster. This new demand foisted upon traditional religious knowledge forces us to look innovatively at

1 Muhȳi al-Dīn Ibn 'Arabī, Fușūṣ Al-Hikam, II (Beirut: Dār al-Kutub al-'Ilmīyah, 2006); Seyyed Hossein Nasr, Man and Nature: The Spiritual Crisis of Modern Man (Chicago: ABC International Group, 1997), 255; Whitney A Bauman, Richard Bohannon, and Kevin J O'Brien, Grounding Religion: A Field Guide to the Study of Religion and Ecology (New York: Taylor \& Francis, 2017). 
our traditions and apply our texts and principles to the pressing problems of today. ${ }^{2}$ It is with astonishing delight, therefore, that our own religious texts - many of them written centuries ago - speak directly on many issues that are relevant to our current problems. Hence, our mission as Muslim researchers is not so much the reinterpretation of our traditions but the reapplication of old teachings and concepts to these new problems.

For the sake of a balanced and sustainable natural environment, we must reconsider our often rather profane view of nature and reevaluate the spiritual spaces in our hearts. A heart that is spiritually awakened and aware strengthens the divine qualities contained in the soul, which means that it will act wisely towards God, fellow humans, and nature. The natural disasters that are visited upon us lately all but indicate the loss of this wisdom we once possessed. A further glance at our past shows that the philosophical and spiritual frameworks applied to ecology are not something new, but something that has been formulated time and again throughout history. ${ }^{3}$

Lately, we have come to accept that the Earth's resources are limited and that we have the responsibility to protect and preserve them. This increasing interest in establishing a harmonious relationship with nature can also be viewed as an indication of an awakening spirituality. Humanity is - at last - beginning to understand that all things are interconnected. Instead of seeing all things as separate, unrelated entities, we are learning to accept the interconnectedness of all things. Freed of the illusion of separateness, we can view the world and all living and non-living things with a renewed sense of respect. If humankind is to enjoy a better relationship with the environment, such a new sense of reverence for nature will certainly be useful. To complete this mission, a new acknowledgment of the sacredness of the natural world is needed. Such a sense of holiness can best be developed through spiritual experiences.

Although some studies of Sufism and environmental ethics have already been carried out in the form of literary studies and field research involving Islamic boarding schools, this particular combination does not constitute a popular research area and is not a major concern in Islamic higher education institutions in Indonesia. Generally, the academic discourse on Sufism still adheres to the classic-normative model and has remained limited to the study of authoritative texts on issues such as maqāmāt (spiritual stations), ậwāl (spiritual states), taniqa (spiritual path), prayer, dhikr (remembrance), tazkiyat al-nafs (self-purification) without reference to current global issues such as protecting the environment. The well-established Sufi concept of mahabbah (love) and tajali (self-manifestation of God), for example, is discussed solely in the context of the love for God and has not yet been extended to the love of

2 Mary Evelyn Tucker and Duncan Ryuken Williams, Buddhism and Ecology: The Interconnection of Dharma and Deeds (Cambridge, MA: Harvard University Center for the Study of World Religions, 1997), https://repository.library.georgetown.edu/handle/10822/899108.

3 Husain Nasr and Seyyed Hossein Nașr, Religion and the Order of Nature (Oxford: Oxford University Press, 1996), 231. 
nature and the environment. So far there are no representative Sufism studies that use this approach by integrating the concepts found in Islamic Sufism with environmental issues. $^{4}$

The need to widen the scope of Sufism by incorporating the concept of tajali and applying it to environmental issues is not a strange and foreign intellectual trend. Such a novel approach of applying traditional concepts to modern issues constitutes a necessary part of our efforts to define the relationship between man and God, between man and man, and also between man and environment. The concept of tajali in the context of environmental protection means the admission and recognition of nature as God's creation that reflects purity and sanctity. While appreciating nature as part of all life that is sacred, the effort to maintain the environment is an indicator of the closeness that should exist between creation and its Creator.

In this piece of research, I intend to explore the doctrine of tajali as developed by Ibn 'Arabī and its potential to be validated as a unique approach to environmental ethics. I also examine the true meaning of God and His creatures and the relationship between them. This area of Sufism study may be considered esoteric but it is relevant for people of all persuasions, even those who are not religious. Its scope is rather academic than devotional, and it is intended as an introduction to the study of Sufism and its implications for the development of environmental ethics.

Ibn 'Arabī's thought can be studied in several scientific works, among them $A$ Mystical Philosophy of Muhyiddīn al-'Arabì by Abū Bakr al-A'lā al-'Afïfī. ${ }^{5}$ The author discusses various views of Ibn 'Arabī such as his metaphysical theory, his doctrines about the universe, epistemology, psychology, ethics, aesthetics, and others. Ibn 'Arabī's teachings have also been studied in relation to Sufi orders. ${ }^{6}$

Among the eminent works that examine his metaphysical views are The Sufi Part of Knowledge: Al-'Arabì's Metaphysics of Imagination and The Self-Disclosure of God: Principles of Ibn al-Arabi's Cosmology by William C. Chittick. ${ }^{7}$ Both works

4 Maghfur Ahmad, "Three Sufi Communities Guarding the Earth: A Case Study of Mitigation and Adaptation to Climate Change in Indonesia," Al-Jami'ah: Journal of Islamic Studies 57, no. 2 (December 24, 2019): 359-96, https://doi.org/10.14421/ajis.2019.572.359-396; Mochammad Lathif Amin, "Eko-Sufisme Islam Aboge Masjid Saka Tunggal Cikakak Banyumas," Jurnal Penelitian 14, no. 2 (June 27, 2017): 131-50, https://doi.org/10.28918/jupe.v14i2.1212; Suwito N.S, "Eko-Sufisme Studi Tentang Usaha Pelestarian Lingkungan Pada Jama'ah Mujahadah Ilmu Giri Dan Jama'ah Aoliya’ Jogjakarta” (Universitas Islam Negeri Syarif Hidayatullah Jakarta, 2010), 12.

5 Abul Ela Affifi, The Mystical Philosophy of Muhyid Dín-Ibnul 'Arabí (Cambridge: Cambridge University Press, 1939).

6 Michel Chodkiewicz, An Ocean without Shore: Ibn Arabi, the Book, and the Law, Suny Press (Albany, NY, 1993); Ian Richard Netton, "An Ocean without Shore: Ibn 'Arabī, the Book and the Law. By Michel Chodkiewicz, Translated from the French by David Streight. Pp. Xiii, 184. Albany, NY, State University of New York Press, 1993. £12.95.," Journal of the Royal Asiatic Society 5, no. 1 (April 24, 1995): 102-102, https://doi.org/10.1017/S1356186300013572.

7 William C. Chittick, The Sufi Path of Knowledge: Ibn Al-Arabi's Metaphysics of Imagination (Albany, NY: Suny Press, 1989); William C. Chittick, The Self-Disclosure of God: Principles of Ibn Al-'Arabi's Cosmology (Albany, NY: Suny Press, 1998).

Teosofia: Indonesian Journal of Islamic Mysticism, Vol. 10, No. 1, 2021

http://journal.walisongo.ac.id/index.php/teosofia 
are the fruits of his systematic study of various metaphysical aspects of Ibn 'Arabī. I would also recommend reading Creative Imagination in the Sufism of Ibn 'Arabì by Henry Corbin ${ }^{8}$ which is an in-depth study of Ibn 'Arabī's mystical parables and spiritual symbols. Cahya Buana focuses on the thought of Ibn 'Arabī and the use of natural symbols in his poetry. ${ }^{9}$ However, what is missing as part of the scientific analysis of Ibn 'Arabỉ's concept of tajall is a new approach to environmental ethics. In this regard, the writers will attempt to validate the concept of tajali in classic Sufism as a concept of environmental ethics.

The writers use literature research combined with a philosophical analysis approach. The method employed to analyze the data is descriptive and productive interpretation, supported by relevant references to the topic being developed. In addition, the writers also construct deep philosophical thoughts to define the meaning of God, man, and nature. The use of hermeneutics is aimed to produce an interpretation of the concept of tajalli which is then validated into an environmental ethic. The main data obtained from the works of Ibn 'Arabī include his Fușūṣ al-Hikam and al-Futūhạàt al-Makkiyya. ${ }^{10}$

\section{B. The Sufi Concept of Nature}

Classic, as well as contemporary Sufi tradition, offers an array of beautiful statements full of wisdom that deal with nature and the environment. In Sufi thought, the relationship between God and nature (cosmos) is very close. Several notable Sufi authorities have written on the environment and have discussed certain ecological topics. In this section, the writers will present some prominent Sufi figures who have given particular attention to nature.

An important figure in the history of Sufi thought was the Muslim philosopher Shihāb al-Dīn al-Suhrawardī. Born in Iran in $1154 \mathrm{CE}$, he established his school of philosophy and was executed in $1191 \mathrm{CE}$ because of his unorthodox teachings. I refer to the words of Abdollah Niksirat who expertly describes Suhrawardī's understanding of nature:

"Suhrawardī's unification of Neoplatonism and Mazdeism finds expression in the conception of an animate universe" where everything is conceived as being the manifestation of the Light of God. The concept of an animate universe in his illuminationist philosophy plays an important role in the new age world as well as in modern spiritual ecology movements. Through the integration of the Neoplatonic concept of the 'chain of beings' in which all creation is a successive

8 Seyyed Hossein Nasr and Oliver Leaman, History of Islamic Philosophy, vol. 1 (England, UK: Routledge, 2013).

9 Cahya Buana, "Nature Symbols and Symbolism in Sufic Poems of Ibn Arabi," KARSA: Journal of Social and Islamic Culture 25, no. 2 (January 7, 2018): 434-56, https://doi.org/10.19105/karsa.v25i2.1304.

10 Muhyī al-Dīn Ibn 'Arabī, Fușūs Al-Hikam; Al-Futûhât Al-Makkīyah (Beirut: Dâr al-Kutub alIlmiyyah, 2011). 
effluence from the original Supreme being, or in Suhrawardī's words the Supreme Light of Lights (nūr al-anwār), Suhrawardī builds a bridge between the transcendental God and nature by viewing that all manifestations on earth have an underpinning, an archetype in the world of pure light. Suhrawardī's universe is intrinsically alive and sacred." 11

Besides Suhrawardī, Ibn 'Arabī is another prominent $12^{\text {th }}$-century figure and is widely regarded as one of the founders of Islamic intellectualism. He was a great philosopher and known as the most theosophic of commentators after Imām alGhazālī. Ibn 'Arabī was born in 560 AH/1165 CE in the city of Murcia, the capital of eastern Andalusia (now Spain). According to Ibn 'Arabī, God is the Creator of all of nature. This is what led him to the conclusion that nature is in essence God himself. In other words, he considers God as the only manifestation of nature as well as the only manifestation of objective reality. The primary aspect of his philosophy is the recognition that there is only a single essence which is God. God is everything, and everything is God.

This concept holds that nothing exists in a way that is independent and enduring except for the ultimate reality that is God. The universe and in consequence human existence depend on God, but God does not depend on them; they can only exist because of His creative power. Ibn 'Arabì is considered as the pioneer of the concept of wahdat al-wujüd (oneness or unity of being) according to which all creatures unite with the essence of God. Ibn 'Arabì frequently describes his concepts and thoughts on Sufism in the form of poems on nature where there is no separation between creat ure and God. In his view, nature is the self-manifestation of God, and God is the essence of nature.

Central to his concept of wahdat al-wujūd of Ibn 'Arabī is tajalliyat al-haqq meaning 'the Truth that manifests itself in nature.' His understanding of tajall is synonymous with emanation. ${ }^{12}$ It is based on the notion that there is only one true existence, namely God's Being which he considers the highest expression of tawhìd (God's unity or oneness). Ibn 'Arabì was not the first Sufi or philosopher to articulate this point, and many scholars before him expressed similar views. ${ }^{13}$

The third prominent Sufi figure is Mawlana Jalāluddīn Muhammad al-Rūmī. He was born in Balkh province (today the border region of Tajikistan and Afghanistan) in $1207 \mathrm{CE}$, his father being a notable Muslim theologian and jurist in his own right. Jalāluddīn al-Rūmī was a passionate student and lover of nature as a lifelong source of

11 Abdollah Niksirat, "Suhrawardi: A Philosopher Who Must Be Re-Known!," Journal of History Culture and Art Research 5, no. 4 (January 5, 2017): 686-94, https://doi.org/10.7596/taksad.v5i4.638.

12 Kautsar Azhari Noer, Ibn Al-'arabi: Wahdat Al-Wujud Dalam Perdebatan (Jakarta: Paramadina, 1995), 25.

13 James Winston Morris, "Ibn 'Arabi and His Interpreters Part II (Conclusion): Influences and Interpretations," Journal of the American Oriental Society 107, no. 1 (January 1987): 101-9, https://doi.org/10.2307/602957.

Teosofia: Indonesian Journal of Islamic Mysticism, Vol. 10, No. 1, 2021 
inspiration. He taught his followers profound respect for nature by pointing at its wonders and the divine secrets it concealed. Muslim scholars refer to nature as 'the Book of the Universe' and argue that the world is entrusted to mankind to learn from it, respect it, and protect it. In other words, we should treat nature respectfully and lovingly by preserving it and not by exploiting and wasting its resources. Nature has to be observed and studied carefully by God's vicegerents in order for them to recognize, acknowledge and revere the Creator behind creation. Rumi never allowed his students, nor allows us as his readers today, to forget that the universe guides us to higher knowledge of our Creator. Mawlāna wrote sublime poetry highlighting the connection between spirituality and nature. His poetry frequently refers to roses, trees, oceans, rivers, and birds to symbolize the soul. His intimate relationship with nature is highly characteristic of his inner experiences, and his elegant and simple expressions reflect an appreciation for both creation and the Creator. ${ }^{14}$

Another prominent work of mystic poetry that invokes nature is Language of the Birds (Manțiq al-T ayr) completed by Farīd al-Dīn 'Attār in 1177 CE. ${ }^{15}$ This famous Persian poem is nearly five thousand couplets long and tells the story of the birds' quest to find a king to lead them. The hoopoe insists that they already have a king, the Simorgh, a magical bird from ancient Iranian mythology, and sets about putting together a group to find him. According to 'Attār's modern interpreters, today's world leaders do not know how to solve the current climate change crisis. Therefore, we should not focus on international agreements and instead use the power in our hands to change things in our own neighborhoods, towns, and cities.

Among the modern Sufi and spiritual leaders worth mentioning is Pir Zia Inayat Khan. He views the current ecological crisis as "a unique and compelling factor in contemporary mysticism." Spiritual schools of today cannot avoid dealing with environmental problems as they are a reflection of the spiritual crisis we are presently witnessing. According to him, the answer to the ecological crisis lies in the acknowledgment of the sacredness of nature and the environment. He argues that spiritual practices are essential in accomplishing this. Rites and prayers can help the practitioners to achieve a state of communion with nature and help to attune them to the environment in a contemplative way. ${ }^{16}$

A similar concern is reflected in the writings of the modern Sufi scholar and intellectual, Seyyed Hossein Nasr (born 1933). One of his concerns is "man's total disharmony with his environment." He sees the crisis as the externalization of an inner disease that cannot be solved without "the spiritual rebirth of Western man." $\mathrm{He}$

14 Ahmad Jalali, "Jalaluddin Rumi's Religious Understanding: A Prelude to Dialogue in the Realm of Religious Thought," Diogenes 50, no. 4 (November 26, 2003): 127-34, https://doi.org/10.1177/03921921030504016.

15 Farīd al-Dīn 'Atțār, Mantiq Ut-Tair (Boulder, Colorado: Shambhala Publications, 1971).

16 Vaughan-Lee Llewellyn, ed., Spiritual Ecology: The Cry of the Earth (California: The Golden Sufi Center, 2013), 25-27. 
argues that human destiny entails fulfilling the role of God's vicegerent on earth and protecting the natural order, thus bearing witness to the truth that the whole of nat ure speaks of God. In his view, the current ecological crisis has its roots in the spiritual and existential crisis of modern man. In several of his books such as Islam and the Plight of Modern Man, ${ }^{17}$ An Introduction to Islamic Cosmological Doctrines, ${ }^{18}$ Religion and the Order of Nature, ${ }^{19}$ Man and Nature: The Spiritual Crisis in Modern Man ${ }^{20}$ Nasr elaborates on the main reasons for the emergence of the environmental crisis in modern society while emphasizing on the importance of reformulating the relationship between human, nature, and God based on spirituality and perennial wisdom.

Another modern scholar of a high caliber is Llewellyn Vaughan-Lee (born in London in 1953). He has followed the Naqshbandi Sufi path since his youth and in 1991 succeeded Irina Tweedie, who brought this particular Indian branch of Sufism to the West. Soon after Vaughan-Lee moved to Northern California and founded The Golden Sufi Center. Author of several books, Llewellyn has specialized in the area of dream interpretation by integrating the classic Sufi approach to dreams with the insights of modern Jungian psychology. For the last two decades, he has been writing on spiritual responsibility in our era of transition and making the call for awakening the global consciousness of oneness. In his most recent writings, he specifically focuses on spiritual ecology. He argues that religious leaders have to remind humankind of the mystery and sanctity of creation. There is a divine spark in the whole world, and people need to be constantly reminded that the value of our planet is much greater than any individual, corporate or national interest. It is the moral obligation of us all to rediscover and reaffirm this compassionate vision of God's gift of creation. VaughanLee has published a collection of essays under the title Spiritual Ecology: The Cry of the Earth ${ }^{21}$ to help create more awareness of the need for a spiritual response to our ecological crisis. Reminiscent of Nasr he understands the present environmental crisis as a physical as well as a spiritual crisis.

\section{Ibn 'Arabì's Concept of Tajali as the Basis for Environmental Ethics}

As the greatest of all Muslim philosophers, Ibn 'Arabì (1165-1240CE) recognized philosophy in the broad, modern sense and not simply as an intellectual discipline (Arabic: falsafah) as represented by Ibn Sīnā and Mullā Saḍrā. Salman Bashier argues that 'the story of Islamic philosophy' commenced with a rationalistic

17 Seyyed Hossein Nasr, Islam and the Plight of Modern Man (London; New York: Longman, 1975), 45.

18 Seyyed Hossein Nasr, An Introduction to Islamic Cosmological Doctrines (Britain: Thames and Hudson Ltd, 1978), 35.

19 Seyyed Hossein Nasr, Religion and the Order of Nature (Oxford: Oxford University Press, 1996), 85.

20 Nasr, Man and Nature: The Spiritual Crisis of Modern Man,... 97.

21 Llewellyn, Spiritual Ecology: The Cry of the Earth,... 26.

Teosofia: Indonesian Journal of Islamic Mysticism, Vol. 10, No. 1, 2021

http://journal.walisongo.ac.id/index.php/teosofia 
phase and culminated in an 'illuminative phase' best represented by Ibn 'Arabī. ${ }^{22}$ Most Western scholarship and much of the later Islamic tradition classified Ibn 'Arabì as a Sufi mystic. On the basis of the comprehensive studies of Henry Corbin ${ }^{23}$ and Toshihiko Izutsu, ${ }^{24} \mathrm{Ibn}$ 'Arabì is known as an extraordinarily broad-ranging and highly original thinker who has contributed extensively to the field of philosophy. These two scholars, however, limited their attention almost entirely to one of his short works, Fușūs al-Hikam (The Ringstones of Wisdom). Although the Fușūṣ was the focus of a long tradition of commentary, it constitutes but a tiny segment of what Ibn 'Arabì has to offer in his massive work al-Futūhāt al-Makkiyya (The Meccan Openings). More recently, scholars have begun to look at this work (which will fill an estimated 15,000 pages in its upcoming edition), but relatively little of it has been translated into Western languages and is still in need of commentary and contextualization. $^{25}$

The central concept of Ibn 'Arabi's wahdat al-wujüd (oneness or unity of being) is the concept of tajali (self-manifestation of God) upon which is his entire philosophical system is founded. Tajall is also the very pillar of his concept of wahdat al-wujü $d$ whereby the many arise from the One. Tajalli can be translated by using various equally valid terms including self-disclosure, self-revelation, selfmanifestation, appearance, and theophany. ${ }^{26}$

The realization that the essence of all beings is unity, and that this unity is a reflection of God will shape the attitudes and guide the actions of the believers. According to Coates, each individual can witness the unity of being. ${ }^{27}$ There is a particular statement in the Fușūṣ al-Hikam and al-Futūhāt al-Makkiyya that reflects this ecological aspect of the unity of being. It reads as follows:

"Because, the whole reality from its beginning to its end comes from God Himself, (and to Him) all is back. Thus, they all require clarification/clarification of the natural mirror; then Adam is identical and clear the mirror and is the spirit of the form (nature). And when the Truth knows Himself, He knows Nature from His Essence, then He takes out nature, then He knows His form, so be that nature as a mirror where He sees His form." 28

Thus, the consciousness of the unity of all things is a state of awareness in which the subject and the object are indistinguishable. It follows that the objectification of

22 Salman Bashier, The Story of Islamic Philosophy: Ibn Tufayl, Ibn Al-'Arabi, and Others on the Limit between Naturalism and Traditionalism (Albany, NY: Suny Press, 2012).

23 Henry Corbin, Creative Imagination in the Sufism of Ibn 'Arabi, vol. 91 (London: Routledge, 2013).

24 Toshihiko Izutsu, A Comparative Study of the Key Philosophical Concepts in Sufism and Taoism: Ibn'arabī and Lao-Tzŭ, Chuang-Tzŭ, vol. 7 (Tokyo: Keio Institute of Cultural and Linguistic Studies, 1966).

25 Annemarie Schimmel, Dimensi Mistik Dalam Islam, trans. Sapardi Djoko Damono and Achadiati Ikram (Jakarta: Pustaka Firdaus, 1986), 121.

26 'Abd al-Munim Al-Hafni, Mu'jam Al-Mustalahat Al-Sufiyah (Beirut: Dar al-Masirah, 1987), 67.

27 Peter Coates, Ibn 'Arabi and Modern Thought (Oxford: Anqa Publishing, 2002), 87.

28 'Arabī, Fușūṣ Al-Hikam,... 107. 
nature in this digital era is no longer applicable. Such a new state of consciousness requires us to acknowledge the ecological activity of our planet, cooperate with it, and respect it as part or even as the essence of our selfhood.

The story of any natural entity that is intrinsically good and the readiness (istida $d$ ) in each is the same as in the parable of the dead letters (sukun) that form a meaningful word when furnished with vowels (harakāt). Ibn 'Arabī explains this parable as follows: The whole cosmos is a letter that comes with meaning, and its meaning is God. He can make His attributes manifest in it, for He is not the locus [in Him] for the manifestation of His attributes. ${ }^{29}$ It describes how each creation has a meaning (intrinsic value) whereby every natural entity is like the letters that make up the word, and the meaning of the word is God Himself. Furthermore, Winkel compares each part of nature to a skeleton of Arabic letters consisting of consonant letters and vowel-driven letters that, given vowels, are given meaning. ${ }^{30}$ Thus, the sequence of letters is intrinsically good and valuable, coming together to form a word.

The other intrinsic value of nature lies in its role as a sign. According to Ibn 'Arabī, the word 'nature' comes from the Arabic word 'alam, derived from the same root as 'alāmah(sign) and 'ilm (knowledge). This word derivation indicates that nature is a source of knowledge and signs that point to something other than itself. ${ }^{31}$ Speaking of the intrinsic value of nature, Ibn 'Arabī provides further context in his other teachings. If nature is a manifestation of God, this means that the scope of nat ure reaches far beyond the material dimension. ${ }^{32}$

Furthermore, the symbolism of the moon in part of Ibn 'Arabì's poetry has a close relationship with the symbolism of the sun. The sun, as described before, has almost the same connotation as the Lord of the universe in the sense that the moon cannot exist without the sun. The moon shines because it receives light from the sun which the Sufis call emanation (fayd). The concept of emanation in creation, namely the gradual coming into existence of entities originating from the One often uses the analogy of the sun and the emanating light. The sun is the source of light and the source of all existence. However, both are not identical: When the sun is gone, there also goes the light..$^{33}$

According to Ibn 'Arabī, God is symbolized in the sun since this natural element transfers light to the entire world and becomes the main source of life. The moon, on the other hand, is the natural element that receives sunlight. Therefore, Ibn 'Arabì uses the symbol of the moon to represent the manifestation (tajali) of God for humankind, like the moon reflecting the sunlight. In terms of describing the relation of God and

29 'Arabī, Fușūṣ Al-Hikam,... 76.

30 Eric Winkel, "La Estructura Geométrica de Los Grados En El Universo de Los Estados Espirituales," El Azufre Rojo, no. 3 (January 1, 1970): 89-118, https://doi.org/10.6018/azufre.274031.

31 'Arabī, Fușūṣ Al-Hikam,... 91.

32 'Arabī, Fușūṣ Al-Hikam,... 91.

33 'Arabī, Fuṣūṣ Al-Hikam,... 91. 
humankind, he often employs the symbolism of sky and earth. Here, the sky represents the divine world ( $(\bar{a} h \bar{u} t)$ while the earth symbolizes the human world (nāsūt). These two worlds completely differ from each other and are connected through the stars (kawākib; nujüm) that beautify both worlds, the divine world above and the earthly below. The stars are also the symbols of the spirit (rūh) that God blew into all living things. Thus, the stars residing inside the human body become a place where the highest attributes of God and the contemptible nature of humans can meet. ${ }^{34}$

According to Ibn 'Arabī, nature is a manifestation (tajalhi) of God. Being His manifestation, the cosmos is none other than the showing of God Who actualizes Himself in His creation. It follows that we owe our highest respect to nat ure which has to be part of our conscious effort to worship God. He likens humankind to a microcosm (al-'alam al-ṣaghìr $r)$ and nature to a macrocosm (al-'allam al-kabìr $r$. Taking care of the planet brings us closer to the Oneness of God, thus spiritually cleansing ourselves and the outer environment as well. God has produced humans as part of His original creation to function within its primordial pattern. Humanity is thus inescapably subjected to God's immutable laws, as is the rest of creation. In this sense, human beings are equal partners with nature and not its masters. If there is an action there is a reaction, according to God's laws. Global warming can be seen, in this light, as the earth's endeavor to preserve a balance in response to the human attack on it. ${ }^{35}$

The concept of tajalh is based on the revealed tradition (hadith qudsi): "I am a hidden treasure, I want to be known. Because of that I created creatures so that I will be known". This hadith is interpreted by Ibn "Arabì as saying that Allah longed for Himself to be known, and so He created the universe to be known by His creation through His creation. The word 'wish' in the hadith indicates that God willed to see Himself; since it was impossible to see Himself without an intermediary, God created the universe. ${ }^{36}$

Ibn 'Arabī's statement can be understood in the sense that all of God's creation constitutes an inseparable dimension of His existence. The existence of a neat and orderly nature indicates the existence of God as its organizer and creator. He regards nature as something living, hearing, seeing, and created out of His love. Nature is considered as the key to knowing God; therefore, nature occupies a key position. It follows that one cannot know Allah without reference to nature since Allah could only be known until He created nature. This is what can be understood from the concept of tajalh. ${ }^{37}$

Ibn 'Arabī understands nature as a reflection of God's various attributes. Natural diversity is a result of God's activity. God reveals His own Glory to nature and through nature to humankind. The appearance of God in natural forms must be understood as

Ibrahim Al-Jilli, Al-Insan Al-Kamil (Beirut: Dar al-Kutub al-Ilmiyah, 1997), 75.

'Arabī, Fușūs Al-Hikam,... 91.

'Arabī, Fușūṣ Al-Hikam,... 91.

'Arabī, Fuṣūs Al-Hikam... 91. 
indirect manifestations of God and His attributes. Ibn 'Arabī emphasizes that nature, in all its various forms, is the expression of the divine will (irā dah). ${ }^{38}$

I propose that Ibn 'Arabī's concept of tajall be taken as the basis for a holistic and integral framework of environmental ethics. The consequences of human actions eventually force mankind to develop a healthy respect for nature. This concept can also serve as a framework - including the warning signs — of the use and management of natural resources. We are forbidden to recklessly and greedily exploit nature without limits. This concept can serve as a point of orientation and motivation to stop us from damaging our environment. By restoring sacred values to nature and science it has answered one of the fundamental problems of modern civilization, namely the environmental crisis.

\section{Tajali as Part of a Spiritual Ecological Framework}

Based on Ibn 'Arabì's concept of tajalli, we understand that we ought to respect and protect nature because it reflects God's glory and power. Since all of creation shares the same divine origin, and we are endowed with intellect ('aqI) and are able to reflect upon the signs, we ought to give nature the respect it deserves. Needless to say that any act of exploiting and causing irreparable damage to our natural environment betrays this spiritual brotherhood existing between us and all other created beings.

When committing ourselves to spiritual purification, we learn to accept that our acts and intentions have a direct and immediate impact on our environment. With our thoughts and feelings, we contribute to the mind and heart of humanity, and our contribution should be positive. Good thoughts and feelings have a lasting and beneficial effect on those around us, living and non-living things alike.

The positive spiritual energy that we channel through our positive thoughts, feelings, and actions reaches beyond the work of our hands. Good thoughts and feelings can help alter the course of our affairs that will ultimately protect the Earth and all of us living on it and from it. We give to this force of love with our spiritual strength, with our feeling of responsibility and obligation to preserve our planet. The Earth is our home, and we all request to live here in harmony and security.

When shifting our outlook on the environment we are taking a big step in the right direction. Once we have truly understood that we do not own the Earth and that by harming the environment we only harm ourselves, our new attitude will influence those around us. Once humanity changes its outlook on nature and recognizes it as what it actually is - a manifestation of God - a paradigm shift is bound to take place, and new movements will appear.

Understanding Ibn 'Arabī's concept of tajalli invites us to feel closer to God and approach nature with more respect. In the context of environmental conservation, of course, this perspective has the potential to be used as an alternative way of raising

38 'Arabī, Fuṣūṣ Al-Hikam... 91. 
environmental awareness. This concept has been greatly influenced by the theories of emanation, illumination (ishrāq), and even mysticism. However, above all else, this concept has its roots in the teachings of Islamic monotheism. Classic Muslim philosophers, with their renowned aptitude for critical analysis and intellectual creativity, developed this theory further. The original concept of emanation as devised by Plotinus, for example, underwent important changes at the hands of Ibn Sīnā, Ibn 'Arabī, and Suhrawardī, and reached its peak in Mullā Saḍrā's transcendent theosophy. In fact, contemporary Muslim philosophers such as Seyyed Hossein Nasr and Murtadha Motahhari have advanced this theory in such a way that it can serve us now as the basis for environmental ethics.

It is a generally accepted fact that religion plays a decisive role in determining morality. To develop a form of enlightened environmental ethics, we need some form of a 'religious experience'. While not rejecting the efficiency of other religious encouragements, the writers find that the Islamic concept of tajal $\hbar$ offers a solid theological foundation for attaining oneness with God through understanding, devotion, and works - all of which create a progressive theory for environmental ethics. Thus, the Sufi concept of tajali deserves further investigation by those promoting new ethical attitudes toward the environment.

We have failed in our guardianship of the planet and have forgotten its sacred nature and purpose, using it merely for our own gain and benefit. We have forgotten to read the signs of God. We are living in a moment in history that will decide the fut ure of our planet for many years, decades, or even centuries to come. Tajalh instills a deep sense of respect for the natural environment, even spiritual kinship. This article maintains that this concept constitutes a powerful tool of protection from many forms of environmental devastation and ruin.

The concept of tajali is a medium for human thought and action as it is allpervasive and enters every aspect of our struggle to improve ourselves. God, the Highest Reality, is One, and everything other than God comes from Him and is related to Him. A true understanding of anything is only possible if the object in view is welldefined in relation to the Divine. The concept of the self-manifestation of God provides a means to experience the Divine in nature, and as such deserves consideration as an important aspect of a comprehensive approach to ecological ethics.

Tajalh focuses on the link between the physical and the metaphysical and offers a unique viewpoint where the spiritual and the ecological unite into a single vision of the immanence of the Divine in nature. Those specializing in comparative religion will find that tajalh, which underlines the connection between nature and the sacred, combines the authoritative voices from Buddhist, Jewish, Christian, and Islamic religious traditions, all of which emphasize the interdependence of all living things in the unity of God. This shared vision found at the core of all religious teachings offers an opportunity for interreligious dialogue regardless of differences in theology. The 
shared understanding of tajalli has the potential to rally all spiritual seekers, irrespective of specific religious association, and bring about a more profound awareness of the sacred origin of creation.

We can help raise the consciousness of the global society by enhancing our own level of consciousness. Joining the ongoing efforts to protect our planet can bring us closer to God. We are thus able to spiritually cleanse ourselves and preserve the environment at the same time. In that sense, all Muslims ought to be nature conservationists by default. Tajali perceives this universe as initiating from God, centered in Him, and returning to Him. The entire cosmos has been created and is being sustained by God according to His divine will, with a specific purpose and design. In short, the epicenter of all things is God. The Sufi concept of tajall teaches us that love is the strongest force in creation, and it is our love for our planet that will restore what we have despoiled, and purify what we have defiled.

\section{E. Conclusion}

Ibn 'Arabī's thoughts on tajali are the continuation of previous ideas developed by classic Muslim philosophers and Sufis including Ibn Rushd, al-Ghazālī, al-Hallāj, and al-Suhrawardī. Undoubtedly, humanity is the channel of God's grace. Our active contribution to the spiritual world causes light to enter the natural realm. Because of our intimate relationship with nature, our inner state is mirrored in the outer order of things. When our inner being turns to darkness and chaos, nature will exhibit the same degree of darkness and chaos. Tajalli prompts us to see ourselves mirrored in nature, and enter into nature's inner meaning by exploring our inner depths. Those who live merely on the surface of their being may regard nature as something to be manipulated and dominated, while those who turn toward the inner dimension of their existence can see nature as a manifestation of the divine and come to understand it in its real sense.

It is upon us all to realize that protecting the Earth is our responsibility and that we cannot pass it on to someone else or ignore the problem. The most significant and pressing message of tajali is that our present ecological crisis is foremost the result of ignoring our spiritual center. The physical world cannot be separated from the metaphysical world, and such an unnatural state of separation can only result in harm. In other words, our physical and spiritual well-being is intimately linked with our ability to remember God and see Him everywhere. 


\section{Bibliography}

Affifi, Abul Ela. The Mystical Philosophy of Muhyid Dín-Ibnul 'Arabí. Cambridge: Cambridge University Press, 1939.

Ahmad, Maghfur. "Three Sufi Communities Guarding the Earth: A Case Study of Mitigation and Adaptation to Climate Change in Indonesia." Al-Jami'ah: Journal of Islamic Studies 57, no. 2 (December 24, 2019): 359-96. https://doi.org/10.14421/ajis.2019.572.359-396.

Al-Hafni, 'Abd al-Munim. Mu'jam Al-Mustalahat Al-Sufiyah. Beirut: Dar al-Masirah, 1987.

Al-Jilli, Ibrahim. Al-Insan Al-Kamil. Beirut: Dar al-Kutub al-Ilmiyah, 1997.

Amin, Mochammad Lathif. "Eko-Sufisme Islam Aboge Masjid Saka Tunggal Cikakak Banyumas." Jurnal Penelitian 14, no. 2 (June 27, 2017): 131-50. https://doi.org/10.28918/jupe.v14i2.1212.

Bashier, Salman. The Story of Islamic Philosophy: Ibn Tufayl, Ibn Al-'Arabi, and Others on the Limit between Naturalism and Traditionalism. Albany, NY: Suny Press, 2012.

Bauman, Whitney A, Richard Bohannon, and Kevin J O'Brien. Grounding Religion: A Field Guide to the Study of Religion and Ecology. New York: Taylor \& Francis, 2017.

Buana, Cahya. "Nature Symbols and Symbolism in Sufic Poems of Ibn Arabi." KARSA: Journal of Social and Islamic Culture 25, no. 2 (January 7, 2018): 43456. https://doi.org/10.19105/karsa.v25i2.1304.

Chittick, William C. The Self-Disclosure of God: Principles of Ibn Al-'Arabi's Cosmology. Albany, NY: Suny Press, 1998.

. The Sufi Path of Knowledge: Ibn Al-Arabi's Metaphysics of Imagination. Albany, NY: Suny Press, 1989.

Chodkiewicz, Michel. An Ocean without Shore: Ibn Arabi, the Book, and the Law. Suny Press. Albany, NY, 1993.

Coates, Peter. Ibn 'Arabi and Modern Thought. Oxford: Anqa Publishing, 2002.

Corbin, Henry. Creative Imagination in the Sufism of Ibn 'Arabi. Vol. 91. London: Routledge, 2013.

'Atțār, Farīd al-Dīn. Mantiq Ut-Tair. Boulder, Colorado: Shambhala Publications, 1971.

Izutsu, Toshihiko. A Comparative Study of the Key Philosophical Concepts in Sufism and Taoism: Ibn'arabī and Lao-Tzŭ, Chuang-Tzŭ. Vol. 7. Tokyo: Keio Institute 
of Cultural and Linguistic Studies, 1966.

Jalali, Ahmad. “Jalaluddin Rumi's Religious Understanding: A Prelude to Dialogue in the Realm of Religious Thought." Diogenes 50, no. 4 (November 26, 2003): 12734. https://doi.org/10.1177/03921921030504016.

Llewellyn, Vaughan-Lee, ed. Spiritual Ecology: The Cry of the Earth. California: The Golden Sufi Center, 2013.

Morris, James Winston. "Ibn 'Arabi and His Interpreters Part II (Conclusion): Influences and Interpretations." Journal of the American Oriental Society 107, no. 1 (January 1987): 101-9. https://doi.org/10.2307/602957.

N.S, Suwito. "Eko-Sufisme Studi Tentang Usaha Pelestarian Lingkungan Pada Jama'ah Mujahadah Ilmu Giri Dan Jama'ah Aoliya' Jogjakarta.” Universitas Islam Negeri Syarif Hidayatullah Jakarta, 2010.

Nasr, Husain, and Seyyed Hossein Nașr. Religion and the Order of Nature. Oxford: Oxford University Press, 1996.

Nasr, Seyyed Hossein. An Introduction to Islamic Cosmological Doctrines. Britain: Thames and Hudson Ltd, 1978.

_. Islam and the Plight of Modern Man. London; New York: Longman, 1975.

- Man and Nature: The Spiritual Crisis of Modern Man. Chicago: ABC International Group, 1997.

- Religion and the Order of Nature. Oxford: Oxford University Press, 1996.

Nasr, Seyyed Hossein, and Oliver Leaman. History of Islamic Philosophy. Vol. 1. England, UK: Routledge, 2013.

Netton, Ian Richard. "An Ocean without Shore: Ibn 'Arabī, the Book and the Law. By Michel Chodkiewicz, Translated from the French by David Streight. Pp. Xiii, 184. Albany, NY, State University of New York Press, 1993. £12.95.” Journal of the Royal Asiatic Society 5, no. 1 (April 24, 1995): 102-102. https://doi.org/10.1017/S1356186300013572.

Niksirat, Abdollah. "Suhrawardi: A Philosopher Who Must Be Re-Known!" Journal of History Culture and Art Research 5, no. 4 (January 5, 2017): 686-94. https://doi.org/10.7596/taksad.v5i4.638.

Noer, Kautsar Azhari. Ibn Al-'arabi: Wahdat Al-Wujud Dalam Perdebatan. Jakarta: Paramadina, 1995.

Schimmel, Annemarie. Dimensi Mistik Dalam Islam. Translated by Sapardi Djoko Damono and Achadiati Ikram. Jakarta: Pustaka Firdaus, 1986.

Tucker, Mary Evelyn, and Duncan Ryuken Williams. Buddhism and Ecology: The Interconnection of Dharma and Deeds. Cambridge, MA: Harvard University 
Center for the Study of World Religions, 1997. https://repository.library.georgetown.edu/handle/10822/899108.

Winkel, Eric. "La Estructura Geométrica de Los Grados En El Universo de Los Estados Espirituales." El Azufre Rojo, no. 3 (January 1, 1970): 89-118. https://doi.org/10.6018/azufre.274031.

'Arabī, Muhyī al-Dīn Ibn. Fușūṣ Al-Hikam; Al-Futûhât Al-Makiyyah. Beirut: Dâr alKutub al-Ilmiyyah, 2011.

—. Fușūṣ Al-Hikam. II. Beirut: Dār al-Kutub al-'Ilmīyah, 2006. 